\title{
Empowerment of Fishermen's wives in Labuhanbatu
}

\author{
Tengku Irmayani ${ }^{1}$, Husnul Isa Harahap ${ }^{2}$, Indra Pandapotan ${ }^{3}$ \\ \{tengku.irmayani@gmail.com ${ }^{1}$, husnul.harahap@usu.ac.id ${ }^{2}$, pandapotan.indra@gmail.com ${ }^{3}$ \}
}

Department of Political Science, Universitas Sumatera Utara, Medan, Indonesia

\begin{abstract}
This study examines empowerment of fishermen's wives in Labuhanbatu. Begin to see the living conditions of fishermen (education and economy) to whether the district government of Labuhanbatu make a policy for the empowerment of fishermen's wives, so as to encourage the improvement of the fishermen's family economy. The study found that there are three main explanations. First, there is no empowerment done by the local government in the fishermen's territory. Second, low education does not change the economy of fishing communities in Labuhanbatu getting better. Third, the lack of financial ability and the skill of the fishermen's wives, which in turn make the fishermen's wives in Labuhanbatu become the woman left behind. The purpose of this study is to initiate an empowerment that can be done by the district government Labuhanbatu in order to raise the degree of fishermen from poverty.
\end{abstract}

Keywords: Women Fisherman, Poverty, Women Empowerment, Coastal Woman

\section{Introduction}

The fishing community is identical with poverty. It does not become a new fact that their lives are below the poverty line. This is due to the limited ability possessed by fishermen and also their families so that they depend only on the sea products that have been provided by nature. The seafood obtained can not cover their daily needs. There should be other sources of income so that the family of fishermen can meet their daily needs. According to Prof. Dr. Tridoyo Kusumastanto, fisherman is the poorest and marginalized society in the social strata of Indonesian society. [1] This is similar to what Dault says is so poor that coastal communities are often called the poorest of the poor. [2]

With such circumstances require the wife of the fisherman to play a dual role in the family that is maintaining the sustainability of households and also run economic activities in order to meet the needs of daily life of his family. In carrying out economic activities to meet the needs of his family, the wife of the fisherman to do the work from being a housekeeper, working in the processing and marketing of fish catch, as well as transporting and cleaning salt is also done by the fisherman's wife.

The People's Coalition for Fisheries Justice (KIARA) notes that at least 56 million people are involved in fishing activities. This activity started from catching, processing, to marketing the catch. Of that amount, 70 percent or about 39 million people are fishermen's wives in Indonesia. [3] This situation continues on an ongoing basis. The same thing is also felt by women fishermen who are in the Bar Hilir. The fishermen women in the place must have a dual role in order that the needs and survival of their family can work properly.

Seeing the existence of a double burden by the fishermen's wife then it requires the empowerment so that the fishermen's wife can hold economic activities not only with their 
energy but through their ability so they will get a much higher pay than if they work only with energy. The question of the study is whether there is empowerment by the Labuhanbatu government towards women's empowerment? And how the empowerment of fishermen's wives so that empowerment can help increase the economic income of fishermen families so that they can meet the needs of their family life.

\section{Method}

This study uses qualitative methods. The data used are primary and secondary data. Data comes from interviews with some citizen, they are mrs. Dewi she is a fish collector, mrs. Ina Koto, she is a fosherman's wife, mr. Sofyan, he is a fisherman and mrs. Zakiya a head of division in fishery department of Labuhanbatu regency. Beside got information from interview, this research used documents which available both online and in print as an information. Data analysis in this research is using qualitative analysis.

\section{Profile of Labuhanbatu}

Kampung Nelayan in Bilah Hilir district, Labuhanbatu regency is one of the villages that almost all of its people work as fisherman. There are 225 Fishermen in this village [4]. Villagers Fishermen use rowing boats or canoes to search for river and sea products such as fishes and shrimps. The results of these rivers and seas will be sold to the fish collectors.

The results obtained by the average fisherman from the sea for a day about 2-3 kilograms of fish. If sold then the fishermen will get money amounting to Rp.50.000 - Rp.75.000, depending on the number, weight and type of fish obtained.There is no other work done by the fishermen when not sailed by nature such as bad weather or tide.There is not other work is done by the fishermen when they are not sailed by nature like bad weather or sea tides.

To help the family economy, the wives of fishermen who must strive to meet the daily needs of their families. The wives of fishermen work as household assistants who are given wages of Rp.50.000, - per day. In addition to being a housekeeper the wife of a fisherman also works as a plantation worker. The result is uncertain about Rp.45.000 - Rp.60.000 per day. It depends on how much work done on that day is planted. [5]

\section{Empowerment of Fishermen's wives}

Poverty in fishing households can at least be grouped into three forms of poverty based on its forming factors [6]. First, structural poverty. This poverty suffered by a group of fishermen because the existing social structural conditions make them unable to participate using the sources of income that is actually available, also due to the policy order more profitable group of capital owners (big fishermen). Strengths outside the households of small fishermen render them marginalized and live in the shackles of poverty. So the problem is the inequality of access to resources because of the social structure that exists. Fishermen in Kampung Nelayan, Labuhanbatu in general are small fishermen who do not have the capital, so that when they go to the sea, they just get very little of sea products. 
Only about 2-3 kilograms of fish and not all of the fish can be sold. As conveyed by mrs. Ina Koto who is the wife of a fisherman. "I am no longer young and hasn't more capital, and in the river or sea there is only fewer fish. I will just spent my energy and I get nothing if only using a boat and a simple net "[7] Meanwhile, to buy equipment to go to sea such as Bolat and boat engine required a lot of capital. And Labuhanbatu district government has never provided assistance to the fishermen in Kampung Nelayan, District Bilah Hilir, Labuhanbatu regency. If any assistance provided by the government of Labuhanbatu is aquaculture assistance. But this assistance is given to community groups who have successfully conducted fish farming. [8]

Second, cultural poverty that sees poverty occurs due to cultural factors such as laziness that originates from local values that are not conducive to progress. This poverty can not be separated from the values adopted by the fishermen's households in living their lives. In the community of the Kampung Nelayan has become commonplace when stopped going to school. Not only for the reason of not having the funds but also because they have no interest and motivation to continue their study. for example is the daughter of Mr Sofyan. His daughter does not want to go to school because she did not have the desire to go to school and finish her primary school [9].

Third, natural poverty occurs where natural conditions that do not support them to engage in productive economic activities or unproductive productive behavior due to the nature of the resources concerned. For example, what happens in Kampung Nelayan Labuhanbatu is when the tide occurs, then the fishermen can not go to sea to catch fish for an unspecified time. Entries that occur may take more than one week to 1 month. This is as revealed by the mrs. Dewi :

"Sebenarnya kalau pasang terjadi kasian juga aku melihat nelayan - nelayan disini. Gabisa dia melautkan, sedangkan dia tak ada kerjaan lain lagi. Kalau aku, suamiku masih ada pekerjaannya sebagai kuli, jadi masih bisa tertolong kami kalau sedang pasang terjadi. Nantipun kalau pasang sudah surut, bisa juga itu kudapat udang - udang dibelakang rumahku, sisa sisa dari pasang. Tapi selama pasang itu tidak ada lah penghasilan dari laut kan. Itu yang memberatkan sebenarnya" [5]

Actually if the tide happens I feel sorry to see the fishermen here. They can not sail, and they has nothing else to do. My husband still has a job as a porter of goods, so it can still help us when a tide occurs. Even if the tide has receded, I can also get shrimps behind my house it is from the rest of the tide that has subsided. But as long as the tide occurs there is no income from the sea. That's the real burden.

For these three reasons it is necessary to empower the fishermen's wives. Moreover, when the weather is not good and the tide is going on, there is nothing the fishermen can do. The district government of Labuhanbatu also has no solutions and policies related to the empowerment of fishermen's wives. With the empowerment of wives, the sources of poverty of the fishing communities can be minimized. Empowerment that can be done in kampung Nelayan, Labuhanbatu to fishermen's wives is by providing learning and also counseling to process the seafood obtained into processed food.

This is because the fishermen of Bilah Hilir especially in the kampung Nelayan have the potential to be developed and empowered. In addition, the ammount of women fishermen in the kampung Nelayan quite a lot. And most of them are at productive age so that they can be empowered. Then the location of the fishing village area adjacent to the sea and bypassed by the river so that there are many marine resources that can be utilized as a base material to be processed food. For example, there are typical Bilah Hilir fishes they are Gamak fishes and Terubuk fishes that can be used as a basic ingredients of processed foods that will be formed 
processed foods such as crackers, nuggets, meatballs and others that have a higher selling value than if only sell as a raw fish to the fish collector.

Therefore, for the empowerment of fishermen's wives in the form of learning and counseling of food preparations required the cooperation between the Regional Devices Work Unit (SKPD) in Labuhanbatu and also in cooperation with Regional Owned Enterprises (BUMD) in Labuhanbatu. Thus empowerment of fishermen's wives will run and will change the condition of the economy and also change the mindset of people who are in the village Nelayang Bilah Hilir district, Labuhanbatu.

\section{Conclusion}

Poverty in fishing communities is not something new. This study discusses the empowerment of wives of the fishermen. Why should fishermen's wives be empowered? First, there is no empowerment done by the local government in the fishermen's territory. Second, low education does not change the economy of fishing communities in Labuhanbatu getting better. Third, the lack of financial ability and the skill of the fishermen's wives, which in turn make the fishermen's wife in Labuhanbatu become the woman left behind. So it is necessary to empower the wives of fishermen which if run well, it will change the conditions and circumstances that exist in the kampung Nelayan community, Bilah Hilir district, Labuhanbatu regency.

\section{References}

[1] Satria.Arif. 2009. Ekologi Politik Nelayan. (Yogyakarta:LKiS).

[2] Dault. A. 2008. Pemuda Dan Kelautan. (Jakarta:Pustaka Cidesindo).

[3] KIARA. 2015. Perempuan Nelayan Berhak Mendapatkan Perlindungan Dan Pemberdayaan Dari Negara. Kiara.or.id, Monday, June $4^{\text {th }} 2018,11.12$ AM

[4] Notes of Head Village ofkampung Nelayan.

[5] Dewi. "Interview on Empowerment of Fishermen Women with Citizen of kampung Nelayan in Kampung Nelayan, Bilah Hilir district, Labuhanbatu regency" April, $19^{\text {th }} 2018$.

[6] Sumodiningrat, Gunawan. 2007. Pemberdayaan Sosial Kajian Ringkas Tentang Pembangungan Manusia Indonesia. (Jakarta : PT. Kompas Media Nusantara)

[7] Koto, Ina. "Interview on Empowerment of Fishermen Women with Citizen of kampung Nelayan in Kampung Nelayan, Bilah Hilir district, Labuhanbatu regency" April, $19^{\text {th }} 2018$.

[8] Zakiyah. "Interview on Empowerment of Fishermen Women with head of division in fishery department, Labuhanbatu district” April, $19^{\text {th }} 2018$.

[9] Sofyan. "Interview on Empowerment of Fishermen Women with Citizen of kampung Nelayan in Kampung Nelayan, Bilah Hilir district, Labuhanbatu regency" April, 19 ${ }^{\text {th }} 2018$. 